\title{
Seasonal Incidence of Brinjal Shoot and Fruit Borer, Leucinodes orbonalis Guene, (Lepidoptera: Crambidae) During Kharif Season
}

\author{
Chetan Nandi $^{1}$, Gangadhar Narabenchi ${ }^{1}$, Sanjeev Jakatimath ${ }^{2 *}$ and M.V. Prafulkumar \\ ${ }^{1}$ Department of Entomology, College of Horticulture, UHS, Bagalkot-587104, Karnataka, India \\ ${ }^{2}$ Department of Plant Pathology, COH, Bagalkot, UHS, Bagalkot-587104, Karnataka, India \\ ${ }^{3}$ Department of Plant Pathology, COB, Bangalore, UHS, BAGAlkot-587104, Karnataka, India \\ *Corresponding author
}

\section{A B S T R A C T}

\begin{tabular}{|l|}
\hline Ke y w o r d s \\
Brinjal shoot and \\
fruit borer, \\
Leucinodes \\
orbonalis.
\end{tabular}

\section{Introduction}

Brinjal (Solanum melongena L.) is one of the most important vegetables in South Asia which accounts for almost fifty per cent of the world's area under cultivation and also popular in some parts of Africa and Central America (Harish et al., 2011). The area under brinjal cultivation in India is estimated at 7.22 lakh ha under cultivation with a production of 134.43 metric tons and productivity of 18.60 tonnes per hectare. In Karnataka, brinjal is cultivated over an area of 16.10 thousand ha with a production of 421.40 thousand tones (Annon, 2014). Unripe fruits are used primarily as vegetable in the country due to its nutritive value, as fruits are consisting of minerals like iron, phosphorous, calcium and vitamins like A, B and C, (Singh et al., 1963). It has been reported as Ayurvedic medicine for curing the diabetes. In addition it is used as a good appetizer, good aphrodisiac, cardiotonic, laxative and reliever of inflammation. Brinjal plants are very much susceptible to insect pests attack right from seedling stage to final harvesting stage. Brinjal is attacked by 53 species of insect pests of which 8 are considered as major pests causing enormous damage to crop in every season in every year (Biswas et al., 1992). Among the major insect pests, brinjal shoot and fruit borer (BSFB), Leucinodes orbonalis 
is considered the most destructive pest of brinjal in India. The yield loss due to the pest is to the extent of 70-92 per cent (Eswara Reddy and Srinivas, 2004; Jagginavar et al., 2009; Chakraborti and Sarkar, 2011).

\section{Materials and Methods}

To study the seasonal incidences of brinjal shoot and fruit borer, Leucinodes orbonalis during kharif season of2014-2015. Field experiments were carried out at College of Horticulture, Bagalkot. The experiment was laid out in a Randomized Block Design. The hybrid, Mahyco Super 10 was raised in 0.5 acre area following recommended agronomic practices (Anon., 2014). The total area is divided and made into five equal sized blocks each measuring $12 \mathrm{~m} \times 10 \mathrm{~m}$. All the agronomic practices were followed to raise the crop as per the recommended package of practices. The plant protection measures for sucking pests were common for all the treatments. But no plant protection measures were taken for brinjal shoot and fruit borer during the entire study period. Weekly metrological data on different weather parameters was recorded throughout the experimental period.

The seasonal incidences of Brinjal shoot and fruit borer was studied through installation of sex pheromone traps and recording infested shoots and fruits at regular interval. Totally five water traps with leucilure was installed in the field in such way that each block having one trap with a minimum of $10 \mathrm{~m}$ inter trap distance by leaving $2 \mathrm{~m}$ from the border. The seasonal incidence of BSFB was studied by recording infested shoots and fruits. For this purpose, ten plants were selected randomly in each block (50 plants from 5 blocks). From each plant, number of healthy shoots, infested shoots and total number of shoots were recorded. To work out per cent fruit damage, weight of healthy fruits, weight of infested fruits and total weight of fruits were recorded at each harvest. The per cent shoot and fruit infestation was expressed by using following formulas;

Number of shoots infested per plant Shoot damage $(\%)=$ $\mathrm{x} 100$

Total number of shoots per plant

Fruit damage $(\%)=\frac{\text { Weight of infested fruits }}{\text { Total weight of fruits }}$

Results and Discussion

Kharif season (2014-2015)

\section{Shoot incidence}

The incidence of shoot borer, L. orbonalis on kharif crop commenced during second week after transplantation (in the month of August) with a mean of 25.55 per sent shoot damage and reached its peak (43.43\%) during eighth week after transplantation i.e. in the month of September (Table 1) (Fig. 1). The present results are in agreement with that of Sing et al., (2000) who reported that the infestation was started at the end of August and reached peak in the third week of September. Similarly, Bharadiya and Patel (2005) also reported that the damage of shoot and fruit borer on shoots was highest during fourth week of September. The present investigations are in partial agreement with that of Jat et al., (2002) who reported that the infestation of brinjal shoot borer commenced one week after transplantation.

\section{Correlation between weather parameters and shoot incidences}

The per cent shoot damage was positively correlated with maximum temperature, average temperature and rainfall $(\mathrm{r}=0.285, \mathrm{r}$ $=0.075$ and $\mathrm{r}=0.037$, respectively). However, these parameters were statistically non- significant. 
Whereas, minimum temperature, morning relative humidity and evening relative humidity had negative non- significant correlation $(\mathrm{r}=-0.189, \mathrm{r}=-0.101$ and $\mathrm{r}=-$ 0.017, respectively) (Table 2). The present findings are in agreement with those of Sing et al., (2000) and Anjali et al., (2012) who reported a positive correlation between temperature and pest multiplication, whereas, it was negatively correlated with relative humidity.

\section{Fruit incidences}

The incidence of BSFB on fruit was noticed during fifth week after transplantation i.e. in the month of September (34.05\%). Thereafter, the infestation increased gradually and reached to its maximum $(51.41 \%)$ during $12^{\text {th }}$ week after transplantation (October month). The infestation persisted up to $18^{\text {th }}$ week after transplantation (second week of December) (Table 1) (Fig. 1).

The present results are in agreement with the results of Shukla and Khatri (2010) and Kumar and Sing (2012) who reported the infestation of fruit borer from October to December. Similarly, Sing et al., (2006), Oommen and Kumar (2004) and Jat et al., (2002) noticed the peak activity of pest on brinjal fruits in first, third and fourth week of October, respectively.

Fig.1 Weekly incidence of brinjal shoot and fruit borer, Leucinodes orbonalis after transplantation during kharif season of 2014-15

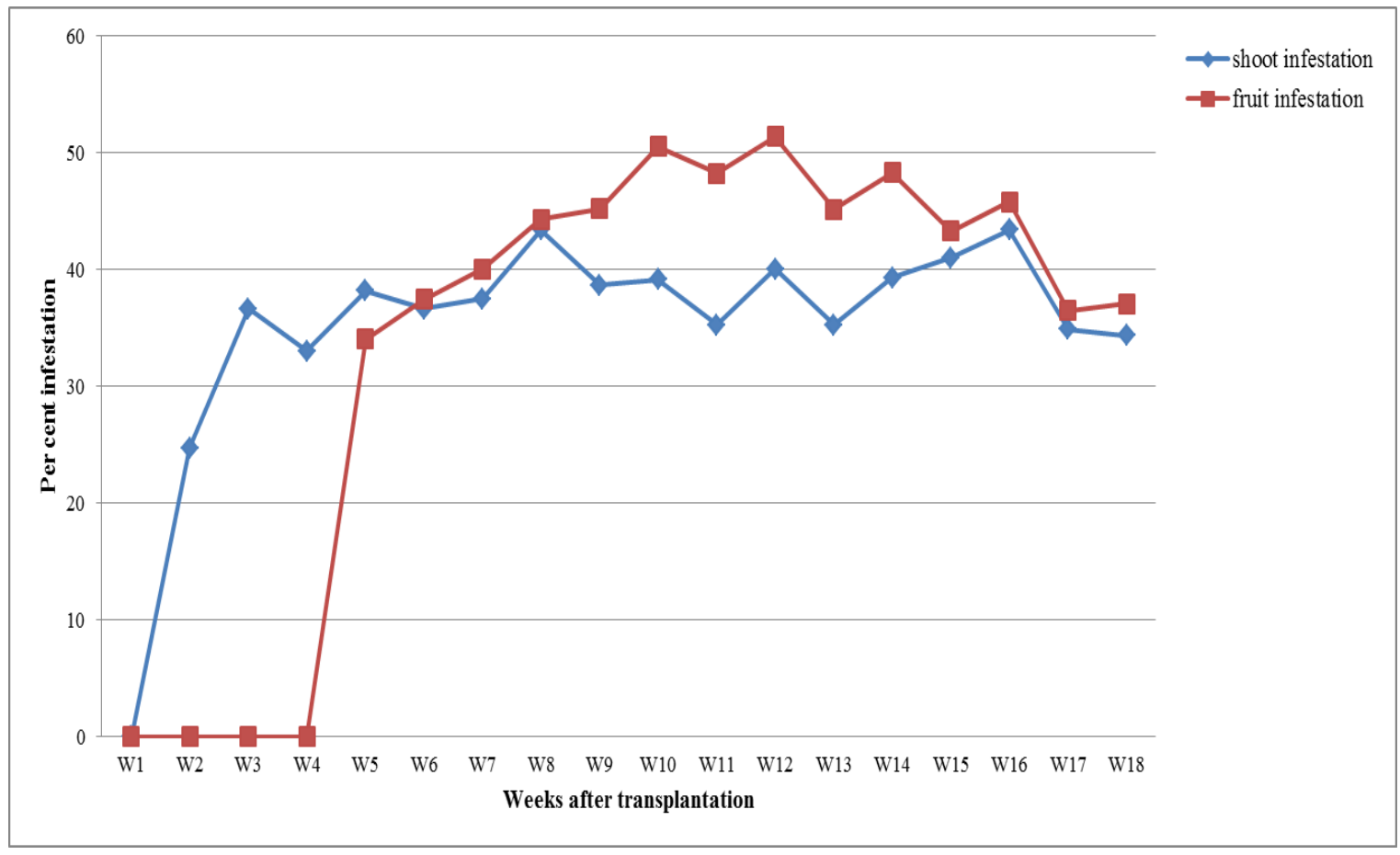


Table.1 Incidence of brinjal shoot and fruit borer, Leucinodes orbonalis at different weeks after transplantation during kharif season

\begin{tabular}{|c|c|c|}
\hline $\begin{array}{c}\text { Weeks after } \\
\text { transplantation }\end{array}$ & Shoot infestation (\%) & Fruit infestation $(\%)$ \\
\hline Week 1 & $\begin{array}{l}0.000 \\
(0.40)^{\mathrm{d}}\end{array}$ & $\begin{array}{c}0.00 \\
(0.401)^{\mathrm{g}}\end{array}$ \\
\hline Week 2 & $\begin{array}{c}25.55 \\
(27.79)^{c}\end{array}$ & $\begin{array}{c}0.00 \\
(0.401)^{\mathrm{g}}\end{array}$ \\
\hline Week 3 & $\begin{array}{c}36.67 \\
(36.93)^{\mathrm{ab}}\end{array}$ & $\begin{array}{c}0.00 \\
(0.401)^{\mathrm{g}}\end{array}$ \\
\hline Week 4 & $\begin{array}{c}33.05 \\
(32.25)^{\mathrm{bc}}\end{array}$ & $\begin{array}{c}0.00 \\
(0.401)^{\mathrm{g}}\end{array}$ \\
\hline Week 5 & $\begin{array}{c}38.20 \\
(38.17)^{\mathrm{ab}}\end{array}$ & $\begin{array}{c}34.05 \\
(35.65)^{\mathrm{f}}\end{array}$ \\
\hline Week 6 & $\begin{array}{c}36.67 \\
(37.00)^{\mathrm{ab}}\end{array}$ & $\begin{array}{c}37.46 \\
(37.70)^{\text {ef }}\end{array}$ \\
\hline Week 7 & $\begin{array}{c}37.53 \\
(37.48)^{\mathrm{ab}}\end{array}$ & $\begin{array}{c}40.08 \\
(39.28)^{\mathrm{de}}\end{array}$ \\
\hline Week 8 & $\begin{array}{c}43.43 \\
(41.22)^{\mathrm{a}}\end{array}$ & $\begin{array}{c}44.35 \\
(41.75)^{\mathrm{bc}}\end{array}$ \\
\hline Week 9 & $\begin{array}{c}38.63 \\
(38.42)^{\mathrm{ab}}\end{array}$ & $\begin{array}{c}45.24 \\
(42.27)^{\mathrm{bc}}\end{array}$ \\
\hline Week 10 & $\begin{array}{c}39.17 \\
(38.68)^{\mathrm{ab}}\end{array}$ & $\begin{array}{c}50.57 \\
(45.32)^{\mathrm{a}}\end{array}$ \\
\hline Week 11 & $\begin{array}{c}35.19 \\
(36.31)^{\mathrm{ab}}\end{array}$ & $\begin{array}{c}48.28 \\
(44.81)^{\mathrm{ab}}\end{array}$ \\
\hline Week 12 & $\begin{array}{c}40.08 \\
(39.24)^{\mathrm{ab}}\end{array}$ & $\begin{array}{c}51.41 \\
(45.81)^{\mathrm{a}}\end{array}$ \\
\hline Week 13 & $\begin{array}{c}35.29 \\
\left(36.37^{\mathrm{ab}}\right.\end{array}$ & $\begin{array}{c}45.17 \\
(42.23)^{\mathrm{ab}}\end{array}$ \\
\hline Week 14 & $\begin{array}{c}39.33 \\
(38.81)^{\mathrm{ab}}\end{array}$ & $\begin{array}{c}48.38 \\
(44.03)^{\mathrm{ab}}\end{array}$ \\
\hline Week 15 & $\begin{array}{c}41.01 \\
(39.79)^{\mathrm{ab}}\end{array}$ & $\begin{array}{c}43.38 \\
(41.19)^{\mathrm{cd}}\end{array}$ \\
\hline Week 16 & $\begin{array}{c}42.50 \\
(40.67)^{\mathrm{a}}\end{array}$ & $\begin{array}{c}45.80 \\
(42.60)^{\mathrm{bc}}\end{array}$ \\
\hline Week 17 & $\begin{array}{c}34.90 \\
(36.20)^{\mathrm{ab}}\end{array}$ & $\begin{array}{c}36.52 \\
(37.17)^{\mathrm{ef}}\end{array}$ \\
\hline Week 18 & $\begin{array}{c}34.39 \\
(35.79)^{\mathrm{abc}}\end{array}$ & $\begin{array}{c}37.10 \\
(37.51)^{\mathrm{ef}}\end{array}$ \\
\hline $\mathrm{SEm} \pm$ & 2.931 & 0.871 \\
\hline CD @ $9 \%$ & 8.245 & 2.458 \\
\hline
\end{tabular}

*Mean of six replications

Figures in parentheses are Arc sine transformed values

Figures in each column followed by same alphabet (s) do not differ significantly at $5 \%$ level 
Table.2 Correlation between weather parameters and incidence of brinjal shoot and fruit borer, Leucinodes orbonalis during kharif season

\begin{tabular}{|c|c|c|}
\hline \multirow{2}{*}{ Weather parameters } & \multicolumn{2}{|c|}{ Correlation coefficient (r) } \\
\cline { 2 - 3 } & Shoot damage & Fruit damage \\
\hline Maximum Temperature $\left({ }^{0} \mathrm{C}\right)$ & 0.285 & 0.291 \\
\hline Minimum Temperature $\left({ }^{0} \mathrm{C}\right)$ & -0.189 & -0.288 \\
\hline Average Temperature $\left({ }^{0} \mathrm{C}\right)$ & 0.075 & -0.036 \\
\hline Rainfall $(\mathrm{mm})$ & 0.037 & -0.347 \\
\hline Relative humidity $(\%)$ I & -0.101 & -0.155 \\
\hline Relative humidity (\%) II & -0.017 & -0.191 \\
\hline
\end{tabular}

Relative humidity I - Morning relative humidity

Relative humidity II - Evening relative humidity

\section{Correlation between weather parameters and fruit incidences}

The incidence of BSFB on fruit was found positively correlated with maximum temperature $(\mathrm{r}=0.291)$ and negatively correlated with other weather parameters such as minimum temperature, average temperature, rainfall, morning relative humidity and evening relative humidity $(\mathrm{r}=-$ $0.288, r=-0.036, r=-0.347 . r=-0.155$ and $r$ $=-0.191$, respectively). These findings clearly indicated that none of the weather parameters had either positive or negative significant influence on population dynamics of BSFB (Table 2).

The present studies get support from the work of Sing et al., (2000), Jat et al., (2002) and Oommen and Kumar (2004) who also obtained similar results. The minimum and average temperature, morning and evening relative humidity and rainfall had nonsignificant effect on borer infestation.

The present findings are in also conformity with those of Naik et al., (2008), Sing et al., (2009) and Shukla and Khatri (2010) who also reported a non-significant effect of minimum temperature, relative humidity and rainfall on the fruit borer infestation.
The studies on seasonal incidences of brinjal shoot and fruit borer during Kharif season revealed that, the peak shoot infestation was noticed around eighth week after transplantation during kharif season. Similarly, the fruit infestation was reached its maximum at $12^{\text {th }}$ weeks after transplantation during kharif season. The incidence of $L$. orbonalis on brinjal shoots showed nonsignificant positive correlation with the maximum temperature, average temperature and rainfall. Whereas, the minimum temperature, morning relative humidity and evening relative humidity recorded nonsignificant negative correlation with shoot incidence. The incidence of L. orbonalis on brinjal fruits indicated non-significant positive correlation with maximum temperature. Whereas, the other weather parameters like minimum and average temperature, morning and evening relative humidity and rainfall showed non-significant negative correlation with fruit incidence.

\section{References}

Anjali, M., Sing, N. P., Mahesh, M. and Swaroop, S., 2012, Seasonal incidence and effect of abiotic factors on population dynamics of major insect pests on brinjal crop. J. Env. Res. Dev., 7 (1A): 431-435.

Anonymous, 2014, Indian Horticulture 
Database, NHB, pp. 131-132.

Bharadiya, A. M. and Patel, B. R., 2005, Study on the efficacy of certain insecticides against brinjal shoot and fruit borer, Leucinodes orbonalis Guenee. J. Pl. Protec. Env., 2 (2): 113-115.

Biswas, G. C., Sattar, M. A. and Seba, M. C., 1992, Survey and monitoring of insects pests of brinjal Khagrachari Hilly Region. Annual Report, 1991-92, Entomological Division, BARI, Joydebpur, Gazipur.

Chakraborti, S. and Sarkar, P. K., 2011, Management of Leucinodes orbonalis Guenee on eggplant during the kharif season in India. J. Pl. Protec. Res., 51(4): 325-328.

Eshwara Reddy and Srinivasa, S. G., 2004, Management of shoot and fruit borer, Leucindoes orbonalis (Guene.) in brinjal using botanicals/oils. Pestology, 28: 5052.

Harish, D. K., Agasimani, A. K., Imamsaheb, S. J. and Patil Satish, S., 2011, Growth and yield parameters in brinjal as influenced by organic nutrient management and plant protection conditions. Res. J. Agri. Sci., 2 (2): 221-225.

Jagginavar, S. B., Sunitha, N. D. and Biradar, A. P., 2009, Bio efficacy of flubendiamide 480 SC against brinjal fruit and shoot borer, Leucinodes orbonalis Guene. Kar. J. Agri. Sci., 22 (3): 712 713.

Jat, K. L., Pareek, B. L. and Singh, S., 2002, Seasonal incidence of shoot and fruit borer (Leucinodes orbonalis Guene.) on egg plant (Solanum melongena L.) in Rajasthan. Annals Bio., 18(2): 165-169.
Kumar, S. and Singh, D. 2012, Seasonal fluctuation and extent of losses of Leucinodes orbonalis Guen. on Solanum melongena L. Ann. Pl. Prot. Sci., 20(2): 318-321.

Naik, V., China Babu., Arjuna Rao P., Krishnayya, P. V. and Srinivasarao, V., 2008, Seasonal incidence and management of Leucinodes orbonalis on brinjal. Annals Plant Protection Sciences, 16: 329-332.

Oommen, S. and Kumar, A., 2004, Seasonal incidence of insect pests of brinjal. Ind. $J$. Appl. Ento., 18 (1): 65-66.

Shukla, A. and Khatri, S. N., 2010, Incidence and abundance of brinjal fruit and shoot borer Leucinodes orbonalis Guene. The Biascan, 5(2): 305-308.

Sing, D. K., Sing, R., Datta, S. D. and Sing, S. K., 2009, Seasonal incidence and insecticidal management of shoot and fruit borer (Leucinodes orbonalis) in brinjal. Annals of Horticulture, 2(2): 187190.

Sing, S., Kumar, A. and Awasthi, B. K., 2006, Seasonal fluctuations and extent of losses of brinjal shoot and fruit borer. Ann. Agri. Res., 27(1): 49-52.

Singh, S. V., Singh, K. S. and Malik, Y. P., 2000, Seasonal abundance and economic losses of shoot and fruit borer, Leucinodes orbonalis on brinjal. Ind. J. Ento., 62(3): 247-252.

Singh, S., Krishna kumar, S. and Katyal, S. L., 1963, Fruit culture in India. Indian Council of Agricultural Research, New Delhi, $412 \mathrm{p}$.

\section{How to cite this article:}

Chetan Nandi, Gangadhar Narabenchi, Sanjeev Jakatimath and Prafulkumar, M.V. 2017. Seasonal Incidence of Brinjal Shoot and Fruit Borer, Leucinodes orbonalis Guene, (Lepidoptera: Crambidae) During Kharif Season. Int.J.Curr.Microbiol.App.Sci. 6(12): 10881093. doi: https://doi.org/10.20546/ijcmas.2017.612.123 